PF 2019 (LXXIII): 413-429

\author{
JAN WIŚLICKI \\ Katedra Lingwistyki Formalnej \\ Uniwersytet Warszawski \\ ul. Dobra 55, 00-312 Warszawa \\ tel. (+48) 225521318 \\ e-mail: jan.wislicki@gmail.com
}

\title{
MORFEMY A WYRAZY SINOJAPOŃSKIE
}

SŁOWA KLUCZOWE: morfemy, wyrazy, afiksy, morfologia, leksykon, japoński

KEYWORDS: morphemes, words, affixes, morphology, lexicon, Japanese

\section{SINO-JAPANESE MORPHEMES AND WORDS}

\begin{abstract}
The aim of this paper is to discuss the morphological status of Sino-Japanese morphemes within Japanese. The analysis focuses on the way they can be merged with other units. Moreover, I discuss the traditional Japanese approach, pointing out differences between affixes and morphemes used for standard compounding. The problem turns out to be non-trivial if the units in question are approached from the point of view of polysystemism; linguistic categories, taken from Chinese (a language where the syntactic position plays the crucial role) to the system of Japanese, with an agglutinative inflection give rise to some interesting problem situated at the morphology-syntax interface of natural languages.
\end{abstract}

\section{Wprowadzenie}

Jednym z podstawowych rozróżnień stanowiących właściwy punkt wyjścia dla szeregu analiz językoznawczych jest to dotyczące samodzielności podstawowych jednostek języka. Zakres tego rozróżnienia rozciąga się przy tym na niemal wszystkie podstawowe gałęzie językoznawstwa. W ramach kluczowego dla pojęcia kompozycji semantycznej wywodzącego się od Gottloba Fregego rozróżnienie to przejawia się w postaci funkcji i argumentu. W teorii składni rozwijanej wg koncepcji generatywnej (Chomsky 2000, 2001) dotyczy ona uzgodnienia (Agre- 
ement), w ramach którego człon składniowo niepełny wchodzi w relację uzgodnienia morfoskładniowego $\mathrm{z}$ członem kompletnym ${ }^{1}$. Nie jest tym samym zaskoczeniem, iż problem ten w równej mierze dotyczy także leksykografii. Aby go krótko zilustrować, odwołajmy się do dwóch artykułów hasłowych przedstawionych w Uniwersalnym słowniku języka polskiego (USJP, wyd. PWN) z 2006 roku:

a-, an- <gr. 'nie, bez'> "pierwszy człon wyrazów złożonych wskazujących na zaprzeczenie lub brak jakiejś cechy, np. asymetria, aspołeczny, anaeroby, anastygmat (a- przed spółgłoską, an- przed samogłoską)»

izm <gr. sufiks -isma, -ismos> książk. iron. żart. «o terminach oznaczających doktryny, teorie, kierunki artystyczne itp.»

Otóż zwróćmy uwagę na pewien fakt. Wykładnik negacji $a$-, an- oraz morfem -izm używany do urabiania nazw teorii, doktryn itp. stanowią typowe przykłady jednostek niesamodzielnych: prefiksów i sufiksów. Ponadto drugi z nich bywa także używany jako wyraz samodzielny i tylko w takiej funkcji widnieje w przytoczonym słowniku. Fakt ten może jednak dziwić o tyle, że zastosowanie tego morfemu jako samodzielnego wyrazu jest pochodne w stosunku do zastosowania niesamodzielnego.

Jak więc widać, nawet leksykograficzny opis tak wyraźnie fleksyjnego języka, jakim jest polszczyzna, stawia pewne wyzwania. Problem ten okazuje się jednak bardziej złożony w wypadku leksykonu sinojapońskiego (tj. wyrazów o pochodzeniu chińskim przeszczepionym do systemu japońskiego). Z jednej strony silnie izolujący charakter języka chińskiego sprawia, iż nakreślenie linii demarkacyjnej między niesamodzielnym morfemem a samodzielnym wyrazem jednomorfemowym staje się szczególnie trudne. Z drugiej zaś jednostki sinojapońskie, przeszczepione do nadrzędnego systemu z fleksją aglutynacyjną, funkcjonują inaczej, niż ma to miejsce w systemie oryginalnym. Zarysowaniu tych różnic poświęcimy poniższą dyskusję.

\section{Problem morfologicznego statusu morfemów sinojapońskich}

Tradycyjne ujęcie leksykograficzne oparte jest na podstawowym rozróżnieniu pomiędzy rdzeniem, tj. jednostką zasadniczo samodzielną ( $\mathrm{z}$ uwzględnieniem odmiany i ewentualnych alomorfów), a afiksem, tj. jednostką niesamodzielną, dołączaną do rdzenia. Aby zarysować trudności zachodzące dla jednostek sinoja-

1 Skrajną wersję prezentują Pesetsky i Torrego (2006), proponując ujęcie, w którym każda operacja składniowa łącząca ze sobą dwa człony musi być licencjonowana przez jakiś typ uzgodnienia. Analizę tego podejścia, wraz z nieco mniej restrykcyjnym wariantem tego ujęcia, przedstawia Wurmbrand (2014). 
pońskich, przyjrzyjmy się wyrazowi muryoku 無力 'bezsilność, słabość, paraliż, niekompetencja, brak środków’ Oba morfemy funkcjonują w takiej samej funkcji, wg standardowego ujęcia odpowiadającej afiksowi. W wypadku pierwszego $\mathrm{z}$ nich jest to funkcja prefiksalna:

$\begin{array}{lll}\text { muishiki } & \text { 無意識 } & \text { 'brak świadomości' } \\ \text { muimi } & \text { 無意味 } & \text { 'bez sensu, bez znaczenia' } \\ \text { mukigen } & \text { 無期限 } & \text { 'bez granic' } \\ \text { musakui } & \text { 無作為 } & \text { 'bez planowania, na chybił trafił' } \\ \text { muteikō } & \text { 無抵抗 } & \text { 'bez oporu, bez sprzeciwu' }\end{array}$

Każdy z powyższych wyrazów, do których dochodzi człon $m u$, stanowi samodzielną jednostkę (ishiki 'świadomość, imi 'znaczenie' etc.). W wypadku drugiego członu jest to funkcja sufiksalna:

$\begin{array}{lll}\text { enshinryoku } & \text { 遠心力 } & \text { 'siła odśrodkowa' } \\ \text { kaizōryoku } & \text { 解像力 } & \text { 'moc powiększenia [np. w mikroskopie]' } \\ \text { gendōryoku } & \text { 原動力 } & \text { 'siła napędowa' } \\ \text { kōchōryoku } & \text { 抗張力 } & \text { 'opór [dosł. „siła oporu”]' } \\ \text { seishinryoku } & \text { 精神力 } & \text { 'siła duchowa' }\end{array}$

Ponownie, każdy z członów, do których dochodzi ryoku, stanowi jednostkę samodzielną. Naturalne byłoby tym samym uznanie obu jednostek za afiksy. Byłoby to jednak równoznaczne ze stwierdzeniem, iż we wspomnianym wyrazie muryoku prefiks łączy się z sufiksem, dając jeden wyraz. Takie ujęcie jest jednak ryzykowne i metodologicznie niejasne. Jeśli bowiem afiks, jako jednostka niesamodzielna wymagająca jednostki samodzielnej, odpowiada w formalnym ujęciu języka funkcji, to jej wartość powstaje poprzez przyjęcie przez tę funkcję argumentu. Jeśli drugą jednostką jest inna funkcja, to w efekcie otrzymujemy złożenie dwóch funkcji. Złożenie funkcji daje natomiast trzecią funkcję. A zatem otrzymany wyraz musiałby być ponownie niesamodzielny, co przeczy danym empirycznym. Ujęcie takie należy więc odrzucić. Pozostaje nam zatem stwierdzenie, iż obie jednostki są jedynie rdzeniami, łączonymi na równi z pozostałymi, a nie dołączanymi na zasadzie (funkcjonalnych) afiksów. To jednak kłóci się wyraźnie nie tylko z intuicjami językowymi, ale także z konkretnym materiałem, który pokazuje, iż oba morfemy funkcjonują inaczej niż te, które nie pozwalają na tworzenie konstrukcji powyższego typu².

2 Kryterium, które wydaje się tutaj dawać szanse na odnalezienie pewnych regularności, jest prozodia. Śledząc akcentuację tego typu wyrazów, można bowiem dostrzec pewne regularności, por:

mukaךnkei 'bez związku'

vs. $\quad$ kankei 'związek' 
Tego typu trudności są też najprawdopodobniej źródłem tego, iż w ramach japońskich badań językoznawczych i filologicznych jednostki sinojapońskie opisywane są przeważnie z perspektywy diachronicznej. Jako kryterium przyjmuje się głównie ich odmienność lub tożsamość z jednostkami klasycznej chińszczyzny, gdy tymczasem ich status morfologiczny jest najczęściej pomijany. W rezultacie wyrazy sinojapońskie postrzegane są w szeregu opracowań (np. Tajima 1998) jako jednostki chińskie. Rzecz jasna, w dorobku badań wschodnioazjatyckich można wskazać pewne odstępstwa. Warto w tym miejscu przywołać termin jikuji 軸字 ‘ideogramy średnicowe’ wprowadzony przez Suzukiego (2010) w odniesieniu do ideogramów, które w XVIII wieku wykazały się szczególnie wysoką produktywnością jako afiksy, wykorzystywane do budowania dwumorfemowych wyrazów japońskich odczytywanych po sinojapońsku i stworzonych na podstawie wzorców chińskich. Przykładowo: dla wyrazów taikō 退校 'opuszczenie szkoły, odejście ze szkoły' i tōkō 登校 'pojawienie się w szkole, uczęszczanie do szkoły’ takim ideogramem średnicowym byłby $k o ̄$ 校 oznaczający tutaj 'szkołę. W języku chińskim jednak ideogram ten takiego znaczenia nie posiadał. Nieco odmienne, odbiegające od tradycyjnej szkoły filologii japońskiej ujęcie proponuje Chén Lìwèi 陳力衛. W tym opisie (Chén 2001), oprócz kategorii odnoszących się do chińskiego wzorca, zostały uwzględnione zarówno ideogramy średnicowe Suzukiego, jak również - w odrębnej kategorii - afiksy. Autor nie omawia szczegółowo morfologii owych jednostek niesamodzielnych. Co więcej, tego typu nieskomentowany szerzej opis stanowi dość ryzykowne uproszczenie. Jako przykład afiksu autor podaje bowiem morfem $h i$ - 非- funkcjonujący jako wykładnik negacji: 'przeciw-, anty-, nie-', np.:
hijōshiki
非常識
'nieracjonalność'
hikokumin
非国民
'wyrzutek społeczny'

muka nkanku 'brak czucia'

muhi Than 'brak krytycyzmu'

ale już:

muka nsa 'niezłożony do oceny'

a także:

muichi 7mon 'bez pieniędzy, bez grosza' vs. ichiาmon 'nieduża ilość pieniędzy'

Jak zatem widać, rozmieszczenie akcentu - choć wykazuje już na pierwszy rzut oka istotne regularności - może różnić się zarówno pod względem rozkładu ilościowego, jak również kompozycyjności semantycznej; w zależności od przykładu zmiana akcentowa może następować po całym morfemie (jak w muichimon) lub w środku (jak w mukansa). Problem ten, $\mathrm{z}$ uwagi na dalsze komplikacje (np. zjawisko root fusion, por. Kurisu 2000), wymaga jednak całkowicie odrębnego opracowania i wykracza poza ramy niniejszej pracy. (Dane fonologiczne zostały zaczerpnięte ze Słownika wymowy i akcentuacji japońskiej 日本語発音アクセント辞典, wydawnictwa NHK, 2008). 


\begin{tabular}{|c|c|}
\hline higōri & 非合理 \\
\hline higōhō & 非合法 \\
\hline
\end{tabular}

Jak jednak wobec tego odnieść się do faktu, iż morfem ten bywa używany samodzielnie, np.:

（1）自分の非を認めない人。

Jibun no hi o mitomenai hito.

'Człowiek nieuznający własnych wad.'

(2) お互いの非をあばきあう。

Otagai no hi o abakiau.

'Wytykać sobie nawzajem wady'

Nawet pobieżny ogląd materiału japońskiego pozwala na postawienie hipotezy, iż wszystkie morfemy sinojapońskie mogą tworzyć większe jednostki, choć odznaczają się różnymi typami łączliwości. Nie wszystkie jednak gotowi jesteśmy określić jako afiksy, jak również nie wszystkie mogą występować w zdaniu lub wypowiedzi samodzielnie. Każdemu z tych typów przyjrzymy się nieco bliżej w następnych podrozdziałach.

\section{Morfemy sinojapońskie}

\subsection{Morfemy samodzielne}

Z morfologicznego punktu widzenia morfemy samodzielne stanowią najmniej złożony przedmiot opisu. Będąc bowiem gramatycznie rzeczownikami, łączą się one w zdaniu bezpośrednio z partykułami lub czasownikami pomocniczymi.

(3) そしてその利は自分ただひとりで受けるのではない。

Soshite sono ri wa jibun tada hitori de ukeru no de wa naku.

'Co więcej, korzyści z tego nie chciałbym zachować tylko i wyłącznie dla siebie’.

（4）彼は10 分ほど席を外したところです。

Kare wa juppun hodo seki o hazushita tokoro desu.

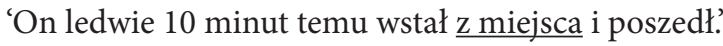

(5) 平和を守るために悪と闘おう。

Heiwa o mamoru tame ni aku to tatakaō.

'Walczmy ze złem, aby chronić pokój'. 
Zdecydowanie rzadziej jednak odnotowuje się przymiotniki niepredykatywne, które funkcję przydawkową pełnią po przyłączeniu partykuły na, morfologicznie przekształcającą rzeczownik w przymiotnik:

(6) 僕は根っからの悪な人っていないと思う。

Boku wa nekkara no aku na hito tte inai to omou.

'Nie wydaje mi się, żebym miał być z natury złym człowiekiem.'

Drugi typ realizowany jest poprzez połączenie z czasownikiem posiłkowym, przede wszystkim suru, morfologicznie przekształcającym rzeczownik w czasownik:

(7) 違反すると 2 年以下の懲役または 300 万円以下の罰金に処されます。 Ihan suru to ninen ika no chōeki mata wa sanbyakuen ika no bakkin ni shosaremasu. 'Za złamanie prawa zostaje się skazanym na dwa lata pozbawienia wolności lub grzywnę do trzech milionów jenów.

(8) 今回の勝敗を決したのは、予測しがたい天候による突然のこの大雪。

Konkai no shōhai o kesshita no wa, yosoku shigatai tenkō ni yoru totsuzen no kono òyki.

'Tym, co tym razem zadecydowało o wyniku, była nagła śnieżyca w tej nieprzewidywalnej aurze pogodowej'.

Kategoria morfoskładniowa jednostek podkreślonych w powyższych przykładach nie budzi większych kontrowersji; formalnie rzecz biorąc, mamy tu zawsze do czynienia z przekształceniem rzeczowników w przymiotniki (w wypadku partykuły na) lub czasowniki (dla czasownika posiłkowego suru). Tym, co może otwierać pole do dalszej dyskusji, jest fakt, iż klasa ta obejmuje jednostki, które wymagają dodatkowych morfemów samodzielnych (Shibatani (2017), co klasyfikuje je w ramach szeroko pojętej klasy compound formatives. Termin ten zakłada jedynie, że nie mamy tu do czynienia $z$ afiksacją, jednak nie wyjaśnia $\mathrm{w}$ żadnej mierze statusu formalnego tych jednostek, w szczególności nie wskazuje precyzyjnie, czy są to funkcje (a jeśli tak, to o jakich dziedzinach), czy też są to argumenty. Pomocna może tu być klasyfikacja przyjęta przez Kobayashiego, Yamashitę i Kageyamę (2016), którzy wydzielają relacje mogące zachodzić zarówno między morfemami w pełni samodzielnymi, jak i tzw. morfemami związanymi, nietraktowanymi jako funkcje (choć, jak pokazuje Nagano (2016), ich status morfologiczny i kwestia związku z partykułami nie jest bezproblemowa). Jednostki te są jednak samodzielne w sensie formalno-semantycznym. Zdecydowanie większe trudności z punktu widzenia samej morfologii można zaobserwować dla kategorii afiksów, do której przejdziemy poniżej. 


\subsection{Afiksy}

Zjawisko afiksacji w wypadku wyrazów sinojapońskich okazuje się problemem dość złożonym. $Z$ pozoru stanowi tu zagadnienie prostsze, niż ma to miejsce w wypadku języków fleksyjnych. I tak przykładowo jest problemem spornym to, czy w wyrazach the, this, that, those możemy mówić o istnieniu wspólnego prefiksu th-, tak jak prezentuje to Di Sciullo (2009), klasyfikując je jako 'operator affixes'. Dyskusyjność owa zaś bierze się stąd, iż samo pojęcie afiksu nie jest dostatecznie precyzyjne. $Z$ całą pewnością jednak nie ogranicza się ono do powtarzalności danych jednostek na danej pozycji w odrębnych wyrazach. Istnienie afiksu jest jednak przede wszystkim uwarunkowane istnieniem rdzenia (Bauer 1994; Carstairs-McCarthy 2006).

Wyrazy sinojapońskie stawiają tutaj trudność zupełnie innego rodzaju. Otóż można zaryzykować stwierdzenie, iż termin ten w odniesieniu do wyrazów rdzennie chińskich, przeszczepionych następnie do japońszczyzny, jest mało użyteczny. Został on bowiem opracowany w odniesieniu do fleksyjnych języków indoeuropejskich i nie znajduje informatywnego zastosowania w opisie tak silnie izolującego języka, jakim jest chińszczyzna. Pobieżny rzut oka na leksykon chiński pozwala bowiem stwierdzić, iż znakomita większość jego jednostek to wyrazy dwumorfemowe, w wypadku których nie tylko stosunek ilościowy potencjalnego rdzenia do afiksu ma się jak 1:1, ale także prymarność semantyczna stanowi kwestię dyskusyjną. Powyżej przywołaliśmy jako przykład wyraz muryoku 無力 'bezsilność, słabość, paraliż, niekompetencja, brak środków', pokazując, iż oba morfemy mogą służyć jako afiksy. Przykładów takich jest w leksykonie chińskim i sinojapońskim (tutaj ograniczamy się do tego drugiego) bardzo wiele, np.:

$\begin{array}{lll}\text { hankan } & \text { 反感 } & \text { 'antypatia, antagonizm, uczucie wrogości' } \\ \text { zenkan } & \text { 全館 } & \text { 'cały budynek' } \\ \text { saikai } & \text { 再会 } & \text { 'ponowne spotkanie' } \\ \text { shishitsu } & \text { 私室 } & \text { 'prywatny pokój' } \\ \text { isetsu } & \text { 異説 } & \begin{array}{l}\text { 'odmienna koncepcja, odmienna teoria } \\ \text { odmienny pogląd' }\end{array}\end{array}$

Każdy z dziesięciu morfemów w wymienionych wyżej wyrazach funkcjonuje w języku japońskim także jako jednostka afiksalna. Powstaje wobec tego problem, jak zdefiniować afiks w odniesieniu do jednostek sinojapońskich.

Otóż wydaje się, iż przede wszystkim o afiksacji tego typu jest sens mówić tylko w dwóch wypadkach: kiedy wyraz sinojapoński jest przynajmniej trójmorfemowy lub gdy morfem sinojapoński dochodzi do wyrazu pochodzenia niechińskiego (japońskiego, angielskiego etc.). Warto zwrócić uwagę, iż oba kryteria mają pewną wspólną cechę: opierają się na odejściu od prymarnego dla tych 
morfemów charakteru chińskiego (a w każdym razie klasyczno-chińskiego); trójmorfemowe jednostki sinojapońskie występowały bowiem w chińszczyźnie jedynie sporadycznie. W następnych podrozdziałach przedstawimy cztery typy afiksów sinojapońskich, które naszym zdaniem można wskazać w tym języku.

\subsubsection{Prefiksy i sufiksy}

Afiksy pre- i postpozycyjne stanowią, jak się wydaje, jedyny typ afiksów sinojapońskich, którego istnienia nie kwestionują żadne teoretyczne leksykograficzne opracowania japońszczyzny ${ }^{3}$. Co więcej, ich szczególna produktywność, odznaczająca się m.in. w łączliwości zarówno z wyrazami jednomorfemowymi, jak i frazami, przesądza o ich specjalnym statusie morfoskładniowym (por. Kageyama 2001 i zaproponowaną tamże składnię dla tego typu wyrazów zwanych word plus). Choć wywodzą się one z morfemów chińskich, ich zastosowanie w konstrukcjach trójmorfemowych stanowi już domenę japońszczyzny. Mogą one dochodzić zarówno do wyrazów chińskich, jak również japońskich lub obcych, jakkolwiek tych pierwszych jest zdecydowanie najwięcej. Wybrane przykłady tego typu jednostek podajemy poniżej:

Prefiksy

- dochodzące do wyrazów sinojapońskich:

$\begin{array}{lll}\text { hikanetsu } & \text { 非加熱 } & \text { 'niewyparzony, nieodkażony' } \\ \text { tansuiro } & \text { 短水路 } & \text { 'krótki basen (przeważnie 25 m)' } \\ \text { honkaigi } & \text { 本会議 } & \text { 'sesja plenarna; ta (dana) konferencja' }\end{array}$

- dochodzące do wyrazów japońskich

\begin{tabular}{|c|c|c|}
\hline kanbashitta & 甲走った & 'bardzo wysoki, piskliwy (głos)' \\
\hline eosareru & 気圧される & $\begin{array}{l}\frac{\text { 'czuć się jakoś (w nie do końca }}{\text { zrozumiały sposób) naciskany, }} \\
\text { zdominowany' }\end{array}$ \\
\hline no & 晚宗 & 'późny (kwietniowy, majowy) szron' \\
\hline
\end{tabular}

- dochodzące do pozostałych wyrazów

$\begin{array}{lll}\text { hanyudaya } & \text { 反ユダヤ } & \text { 'antysemicki' } \\ \text { mukokoa } & \text { 無ココア } & \text { 'bez dodatku kakao' } \\ \text { funaisu } & \text { 不ナイス } & \text { 'nieudany, nieładny, niemiły' }\end{array}$

\footnotetext{
3 Por. artykuły hasłowe odnośnie afiksacji, m.in. w: Nihongo kenkyū to nihongo kyōiku (1999, wyd. Meiji shoin), Kokugo kyōiku jiten (2001, wyd. Asakura shoin), Gengogaku daijiten (1996, wyd. Sanseidō). Wszystkie powyższe pozycje stanowią wiodące leksykograficzne opracowania lingwistyki japońskiej; żaden z nich nie wymienia ani jednego afiksu sinojapońskiego innego niż prefiks lub sufiks. Dodatkowe argumenty wywodzące się z danych statystycznych dotyczących afiksów przedstawia Miyaoka i Tamaoka (2005).
} 
Sufiksy

- dochodzące do wyrazów sinojapońskich:

\begin{tabular}{|c|c|c|}
\hline keizairon & 経済論 & $\begin{array}{l}\text { 'badania nad gospodarką, o gospodarce, } \\
\underline{\varnothing} \text { gospodarka (jako tytuł)' }\end{array}$ \\
\hline kanshajō & 感謝状 & ‘list z podziękowaniami’ \\
\hline gaimushō & 外務省 & 'ministerstwo spraw zagranicznych' \\
\hline
\end{tabular}

- dochodzące do wyrazów japońskich

$\begin{array}{lll}\text { odorokikan } & \text { 驚き感 } & \text { 'uczucie zaskoczenia' } \\ \text { asobihi } & \text { 遊び費 } & \text { 'koszty zabawy, imprezy' } \\ \text { okorinbō } & \text { 怒りん坊 } & \text { 'nerwus' }\end{array}$

- dochodzące do pozostałych wyrazów

$\begin{array}{lll}\text { bijinesuyō } & \text { ビジネス用 } & \text { 'na użytek biznesu' } \\ \text { supōtsudan } & \text { スポーツ団 } & \text { 'drużyna, ekipa sportowa' } \\ \text { eakonkurīninguya } & \text { エアコンクリーニング屋 } & \text { 'zakład czyszczenia } \\ & & \text { klimatyzacji' }\end{array}$

Wskazanie afiksu nie przedstawia tutaj specjalnych trudności. W wypadkach, w których z czysto morfologicznego punktu widzenia jako afiks mogą być postrzegane oba skrajne morfemy, decyduje istnienie określonego rdzenia. I tak przykładowo w poniższych wyrazach morfemy 式 shiki 'styl', 前 zen 'przed' i 反 han 'przeciw' funkcjonują w japońszczyźnie jako afiks:

$\begin{array}{lll}\text { hikōshiki } & \text { 非公式 } & \text { 'nieformalny' } \\ \text { zensōkyoku } & \text { 前奏曲 } & \text { 'preludium (jako forma muzyczna)' } \\ \text { hankō } \underline{k i} & \text { 反抗期 } & \text { 'okres buntu' }\end{array}$

Niemniej we wszystkich tych wyrazach identyfikacja afiksów jest jednoznaczna, jako że we współczesnej japońszczyźnie nie istnieją jednostki ${ }^{\star} h i k o \bar{~}$ 非公, ${ }^{\star}$ sōkyoku 奏曲, ${ }^{\star} k o ̄ k i$ 抗期. Wobec powyższego teoria lingwistyczna pozostawia nam dwa wyjścia: mamy do czynienia albo ze zwykłymi morfemami słowotwórczymi, albo z cyrkumfiksami. I właśnie tym drugim zjawiskiem zajmiemy się w następnej części.

\subsubsection{Cyrkumfiksy a złożenia prefiksalno-sufiksalne}

Jak wspominaliśmy wyżej, żadne ze źródeł japońskich wykorzystanych w tej pracy nie podaje afiksów sinojapońskich innych niż dwa omówione wcześniej typy. Nie oznacza to, że negują one całkowicie istnienie tego typu afiksacji w języku japońskim; podawany jednak nagminnie cyrkumfiks $o$-[czasownik]-ni naru jako wykładnik aprecjatywnej formy czasownika (okaki ni naru 'KTO jest łaskaw na- 
pisać', oyomi ni naru 'KTO jest łaskaw przeczytać') jest jednak rodzimą jednostką japońskąa ${ }^{4}$ Pozostaje pytanie, czy istnieją cyrkumfiksy sinojapońskie.

Zanim rozważymy konkretny materiał językowy, warto poczynić pewną uwagę natury teoretycznej. Otóż przede wszystkim - i tutaj znajduje swoje źródło trudność w znalezieniu cyrkumfiksów sinojapońskich - jednostka taka nie może być zwyczajnym połączeniem prefiksu i sufiksu (por. Carstairs-McCarthy 2006). Musi być ona w jakiś sposób informatywna (morfoskładniowo bądź semantycznie) w stosunku do obu skrajnych afiksów. Jeśli zaś, jak wspominaliśmy wcześniej, przedstawić afiks jako funkcję, to warunek ten sformalizować można w następujący sposób: jeżeli prefiks oznaczymy jako funkcję p-(x), sufiks zaś jako -s(x), to o cyrkumfiksie możemy mówić wyłącznie wówczas, gdy:

$$
p-(-s(\mathrm{x})) \neq-s(p-(\mathrm{x}))
$$

W przeciwnym wypadku należy mówić o dwóch niezależnych afiksach, które mogą jedynie występować razem, ale nie powołują odrębnej jednostki leksykalnej.

Jak się jednak okazuje, istnienie tego typu przykładów sinojapońskich nie jest oczywiste. Spójrzmy najpierw na poniższy, stosunkowo prosty przykład. Na pierwszy rzut oka adekwatnym kandydatem na cyrkumfiks może wydawać się konstrukcja $k \bar{o}$ - 抗 ... -zai 剂 oznaczająca środek (-zai 剂) na CO, lek na CO, lek przeciw-, anty- (kō- 抗)', np.:

$\begin{array}{lll}\text { kōganzai } & \text { 抗癌剤 } & \text { 'lek przeciwnowotworowy' } \\ \text { kōenshōzai } & \text { 抗炎症剤 } & \text { 'lek przeciwzapalny' } \\ \text { kōshuhekizai } & \text { 抗酒癖剂 } & \text { 'lek na uzależnienie alkoholowe' } \\ \text { kōhisutaminzai } & \text { 抗ヒスタミン剤 'środek przeciwhistaminowy' }\end{array}$

Okazuje się jednak, iż widoczna regularność nie zapewnia jeszcze informatywności w stosunku do złożenia prefiksu z sufiksem. Jak najbardziej dopuszczalna jest bowiem wariancja z opuszczaniem któregokolwiek z obu afiksów, np.:

(9) これは抗炎症の重要な要素の一つとなっている。 Kore wa kōenshō no jūyō na yōso no hitotsu to natte iru.

'To jest jeden z ważnych składników przeciwzapalnych'.

(10) 授乳中でも飲める歯の炎症剤はありますか。

Junyūchū de mo nomeru ha no enshōzai wa arimasu ka.

'Czy jest jakiś środek na zapalenie zęba, który można pić nawet podczas karmienia piersią?’

4 To samo tyczy się analogicznej konstrukcji modestywnej o-[czasownik]-suru, np. omise suru 'pozwolę sobie pokazać, okiki suru 'pozwolę sobie zapytać' itd. 
Jak widać, oba afiksy można opuszczać, co stanowi argument za uznaniem całej konstrukcji za złożenie dwóch funkcji z jednym argumentem (rdzeniem). Zwróćmy jednak uwagę na jeden istotny fakt: opuszczenie prefiksu (i tylko jego) nie wpływa na zmianę znaczenia. Lek, środek etc. może być bowiem wyłącznie przeciwko temu, co wskazane jest w rdzeniu. Natomiast to, co ma określone działanie, nie musi być lekiem, lecz składnikiem, a także działaniem, efektem, mechanizmem, np.:

$\begin{array}{lll}\text { kōenshō no sayō } & \text { 抗炎症の作用 } & \text { 'działanie przeciwzapalne' } \\ \text { kōenshō no kōnō } & \text { 抗炎症の効能 } & \text { 'efekt przeciwzapalny' } \\ \text { kōenshō no mekanizumu } & \text { 抗炎症のメカニズム } & \text { 'mechanizm } \\ & & \text { przeciwzapalny' }\end{array}$

Istnieje zatem uzasadniony argument za tym, aby opuszczenie prefiksu uznać za skrót od cyrkumfiksalnej konstrukcji pierwotnej.

Zanim przejdziemy jednak do ogólniejszych wniosków, przypatrzmy się najpierw podobnemu przykładowi. Otóż w ramach terminologii z zakresu geometrii jednym z podstawowych terminów jest pojęcie figur i brył foremnych, zwanych też niekiedy prawidłowymi. Japoński oferuje tutaj regularną strukturę w ramach układu: sei- 正- ... -kei -形 oraz sei-正- ... -tai -体, przy czym prefiks oznacza 'prawidłowy, foremny', zaś sufiks określa typ obiektu, np.:

$\begin{array}{lll}\text { seisankakukei } & \text { 正三角形 } & \text { 'trójkąt równoboczny' } \\ \text { seishikakukei } & \text { 正四角形 } & \text { 'kwadrat' } \\ \text { seihōkei } & \text { 正方形 } & \text { 'kwadrat' } \\ \text { seirokkakukei } & \text { 正六角形 } & \text { 'sześciokąt foremny' } \\ \text { seishimentai } & \text { 正四面体 } & \text { 'ostrosłup foremny' } \\ \text { seihachimentai } & \text { 正八面体 } & \text { 'ośmiościan foremny' }\end{array}$

Regularność sugeruje możliwość postulowania istnienia cyrkumfiksu. Warto jednak rozważyć, czy przedstawione wyżej konstrukcje nie stanowią zwykłego złożenia dwóch afiksów. Z całą pewnością istnieją bowiem wyrazy posiadające wyłącznie jeden ze wspomnianych członów, tj.:

$\begin{array}{lll}\text { sankakukei } & \text { 三角形 } & \text { 'trójkąt' } \\ \text { shimentai } & \text { 四面体 } & \text { 'ostrosłup' }\end{array}$

Jak się jednak okazuje, we współczesnej japońszczyźnie, zwłaszcza w jej nieformalnym użyciu, wskazać można także wyrazy, w których opuszczony jest sufiks, ale pozostawiony prefiks, tj. seisankaku, seishimen itd. Jednostki tego typu (zwłaszcza w odniesieniu do brył) występują stosunkowo sporadycznie. I tu jednak wydaje się zachodzić obserwowane wcześniej zjawisko. Nie ulega bowiem wątpliwości, iż wyraz seisankaku oznacza trójkąt równoboczny (tj. figurę, którą 
denotuje w japońszczyźnie sufiks -kei); podobnie sprawa wygląda w wypadku brył. Widzimy więc wyraźnie, iż w obu przytoczonych wyżej konstrukcjach, tj. 'leku przeciw-' oraz 'figury / bryły foremnej', mamy do czynienia wyłącznie ze skrótami. Proces słowotwórczy przebiega tu wyraźnie od konstrukcji dłuższej do krótszej. Nie sposób tu zatem mówić o derywacji poprzez dodanie afiksu, lecz o urobieniu sekundarnej formy skrótowej. Sekundarność ową potwierdza wyraźnie frekwencja. Przedstawioną cechę obu konstrukcji możemy więc ująć w następujący sposób (strzałka wyznacza pochodzenie słowotwórcze):

$$
\begin{aligned}
& \text { sei-(-kei(sankaku) })=\text { sei-(sankaku }) \quad \text { oraz } \quad \text { seisankaku } \leftarrow \text { seisankakukei } \\
& k \bar{o}-(-z a i(\text { enshō }))=-z a i(\text { enshō }) \quad \text { oraz } \quad \text { enshōzai } \leftarrow k \bar{e} \text { enshōzai }
\end{aligned}
$$

Wydaje się, iż powyższego typu równości oraz wskazanie formy dłuższej jako semantycznie prymarnej pozwalają na postulowanie istnienia cyrkumfiksu. Niemniej w języku japońskim można odnaleźć przykłady jeszcze klarowniejsze. Otóż za tego typu jednostkę należy uznać konstrukcje typu:

$$
\begin{aligned}
& \text { shin- 親- ... - } k a \text { 家 } \\
& h a n \text {-反-... -ka 家 } \\
& \text { chi-知- ... - ka 家 'znawca danego kraju' }
\end{aligned}
$$

W konstrukcjach tych miejsce rdzenia uzupełniane jest przez nazwę kraju (często jego skrót), np.:

$\begin{array}{lll}\text { shindoitsuka } & \text { 新ドイツ家 } & \text { 'germanofil' } \\ \text { hannichika } & \text { 反日家 } & \text { 'osoba antyjapońska' } \\ \text { chichūka } & \text { 知中家 } & \text { 'znawca Chin' }\end{array}$

Propozycja ta nie jest jednak bezdyskusyjna. Otóż po pierwsze, w ramach domniemanego rdzenia może występować jednomorfemowy skrót (Nichi 日 $\leftarrow$ Nihon 日本 Japonia, Futsu 仏 $\leftarrow$ Furansu フランス Francja itd.), a nie pełna nazwa kraju. Tym samym może tu być mowa nie o rdzeniu i cyrkumfiksie, ale najzwyklejszej serii morfemów słowotwórczych. Pozostaje jednak faktem, iż skróty tego typu są tylko opcjonalne; konstrukcja ta dopuszcza bowiem także pełne nazwy krajów. Oprócz przytoczonego 'germanofila' za przykład może posłużyć wyraz shinnihonka 親日本家 ‘japanofil', którego występowanie stanowi argument o tyle silny, iż konstrukcję shinnichika można uznać za sfrazeologizowaną.

Drugi zarzut może dotyczyć ostatniego morfemu -ka, a dokładniej tego, iż stanowi on sufiks (a nie część cyrkumfiksu) w takich wyrazach, jak: 


$\begin{array}{lll}\text { shōsetsuka } & \text { 小説家 } & \text { 'pisarz' } \\ \text { kakumeika } & \text { 革命家 } & \text { 'rewolucjonista' } \\ \text { kūsōka } & \text { 空想家 } & \text { 'marzyciel, osoba snująca nierealne } \\ & & \text { plany' }\end{array}$

Nie znaczy to jednak, iż fakt ten pozwala na postulowanie istnienia sufiksu w wymienionych wyżej przykładach. Nie istnieją bowiem wyrazy ${ }^{*}$ nichika 日家, ${ }^{*}$ doitsuka ドイツ家 itd. Posługując się więc wprowadzonym wyżej kryterium, poniższa równość nie zachodzi (fakt ten oznaczamy gwiazdką):

${ }^{*} \operatorname{shin}-(-k a($ doitsu $))=-k a(\operatorname{shin}-($ doitsu $))$

Dzieje się tak z tego względu, iż funkcja - $k a$ nie daje żadnej wartości dla argumentu (doitsu); nie należy on zwyczajnie do jej dziedziny. Wobec powyższego stoimy na stanowisku, iż konstrukcję tę można z powodzeniem sklasyfikować jako sinojapoński cyrkumfiks, podobnie jak obie wymienione wcześniej.

Przykładów tego typu jest $\mathrm{w}$ języku japońskim niewiele, głównie z uwagi na izolujący charakter i idącą za tym produktywność oryginalnie chińskich morfemów. Do pełnego opisu afiksacji sinojapońskiej pozostały jeszcze interfiksy, jako że typem afiksów, którego faktycznie nie jesteśmy w stanie wskazać w japońszczyźnie, jest infiks; tymi pierwszymi zajmiemy się w następnym podrozdziale.

\subsubsection{Czy w języku japońskim istnieją interfiksy}

W wypadku interfiksów problem wydaje się prostszy, niż ma to miejsce dla cyrkumfiksów. Za konstrukcje tego typu uznajemy takie, w których dany morfem występuje w ramach jednej jednostki pomiędzy dwoma rdzeniami. Co ciekawe, także temu afiksowi współczesne opracowania odmawiają miejsca w japońszczyźnie. Jednym z bardziej przekonujących kandydatów jest morfem -ken- - 兼oznaczający 'i, łączony $z$, razem $z$ ', np.:

\begin{tabular}{|c|c|c|}
\hline shushōkengaishō & 首相兼外相 & $\begin{array}{l}\text { 'funkcja premiera } \\
\text { łączona z } \\
\text { funkcją ministra spraw } \\
\text { zagranicznych' }\end{array}$ \\
\hline shokudōken’ima & 食堂兼居間 & $\begin{array}{l}\text { ‘pokój jadalny łączony z } \\
\text { salonem’ }\end{array}$ \\
\hline jūtakukenkōjō & 住宅兼工場 & $\begin{array}{l}\text { 'mieszkania razem z } \\
\text { fabryką }\end{array}$ \\
\hline umayakengarēji & 厩兼ガレージ & $\begin{array}{l}\text { 'stajnia połączona z } \\
\text { garażem' }\end{array}$ \\
\hline untenshukenhisho & 運転手兼秘書 & $\begin{array}{l}\text { 'kierowca i sekretarz } \\
\text { w jednej osobie' }\end{array}$ \\
\hline
\end{tabular}


suimongakushakenchishitsugakusha＼cjkstart水文学者兼地質学者 $\begin{aligned} & \text { 'hydrolog } \\ & \text { i geolog w } \\ & \text { jednej osobie’ }\end{aligned}$

Warto przy tym zwrócić uwagę, iż choć funkcja tego morfemu wydaje się jasna, żadne z przytoczonych tu opracowań nie uznaje go za interfiks. W Kenkyusha New Japanese-English Dictionary przedstawiony jest on jako spójnik:

keרn 兼 conj. and; in addition; concurrently; at the same time

Redaktorzy Nouveau petit royal dictionnaire japonais-français uznają go dla odmiany za sufiks:

-けん [-兼] 食堂兼居間 salle à manger servant aussi de salle de séjour $f$.

-ken [-兼] 『 shikudōken’ima 食堂兼居間 ‘pokój jadalny łączony z salonem’ żeńsk.

Dizionario Shogakukan giapponese-italiano przedstawia go zaś jako jednostkę samodzielną. Tym samym żadne z opracowań nie uwzględnia jego funkcji interfiksalnej.

Podobnego typu przykłady możemy wskazać w wypadku co najmniej dwóch morfemów ustalających stosunek przydawkowy, tj. -jō- -上- oraz -teki- 的-. Choć oba z nich mogą występować jako sufiksy, to nie sposób pominąć ich dwustronnej łączliwości, np.:

$\begin{array}{lll}\text { hōritsujōmondai } & \text { 法律上問題 } & \text { 'kłopoty natury prawnej' } \\ \text { rekishijōjinbutsu } & \text { 歴史上人物 } & \text { 'postaci historyczne' } \\ \text { gyōmujōsagi } & \text { 業務上詐欺 } & \text { 'oszustwo w pracy' } \\ \text { ningentekimisu } & \text { 人間的ミス } & \text { 'ludzki błąd, pomyłka' } \\ \text { shakaitekisekinin } & \text { 社会的責任 } & \text { 'odpowiedzialność } \\ & & \text { społeczná } \\ \text { gakujutsutekikachi } & \text { 学術的価值 } & \text { 'wartość naukowạ' }\end{array}$

Nie sposób natomiast mówić tutaj ani o prefiksacji, ani o sufiksacji, ani też o zroście. Dwie pierwsze opcje wyklucza otoczenie omawianych jednostek przez inne rdzenie; o zroście zaś nie może być mowy, gdyż jego cechą definicyjną jest to, iż dwa rdzenie łączą się bez pośrednictwa odrębnej jednostki. Tym samym więc jednostki te można bez obaw uznać za sinojapońskie interfiksy. 


\section{Podsumowanie}

Dyskusja podjęta powyżej miała na celu zwrócenie uwagi na dwie kwestie. Po pierwsze, ukazane zostały problemy na styku morfologii i składni, jakie powstają na gruncie formalnym przy próbie nakreślenia kryterium samodzielności jednostek językowych. Materiał sinojapoński okazuje się przy tym wykraczać poza proste rozróżnienie na wyrazy (domena składni) i morfemy (domena morfologii). Obrana linia argumentacyjna opierała się tu na fundamentalnym pojęciu funkcji; ujęcie takie pozwala na postawienie pewnych istotnych problemów dotyczących sinojapońskiego systemu afiksacyjnego. Po drugie, omawiany materiał, tj. jednostki sinojapońskie w japońszczyźnie, starano się przedstawić jako wykazujący szczególne cechy na skutek przeszczepienia do języka o fleksji aglutynacyjnej z silnie izolującego języka pozycyjnego. Obserwacja ta otwiera tym samym dodatkowe pole do dyskusji nad wielosystemowością języków jako szczególnego źródła nietypowych zjawisk - zagadnienia badanego od lat przez Romualda Huszczę.

Zagadnieniem, które z całą pewnością zasługuje na odrębną dyskusję, jest zależność statusu morfologicznego jednostek sinojapońskich od ich kształtu prozodycznego. Podejście tego typu, zarysowane m.in. przez Ito i Mestera (2015), zasługuje na wdrożenie tym bardziej, iż wprowadzałoby ostateczne zerwanie $\mathrm{z}$ ujęciem grafocentrycznym, dominującym w tradycyjnym opisie wschodnioazjatyckim. Zasygnalizowane regularności pozwalają natomiast przypuszczać, iż tego typu perspektywa daje istotne szanse na odnalezienie dodatkowych kryteriów stanowiących argumenty w dyskusji morfologicznej.

\section{Źródła leksykograficzne}

Badania nad językiem japońskim i glottodydaktyka języka japońskiego 日本語研究と日 本語教育 (1999), red. Yoshiyuki Morita, Tōkyō: Meiji shoin;

Encyklopedia językoznawstwa 言語学大辞典 (1996), red. Kamei Takashi, Kōnō Rokurō, Chino Eiichi, Nishida Tatsuo, Tōkyō: Sanseidō;

Słownik glottodydaktyczny języka japońskiego 国語教育辞典 (2001), red. Stowarzyszenie Glottodydaktyczne Języka Japońskiego, Tōkyō: Asakura shoin;

Słownik wymowy i akcentuacji japońskiej 日本語発音アクセント辞典 (1998), red. Pracownia Kultury NHK, Tōkyō: NHK;

USJP - Uniwersalny słownik języka polskiego (2006), red. Stanisław Dubisz, Warszawa: PWN. 


\section{Bibliografia}

Bauer, L. (1994). Affication as a Means of Word-formation. W: R. E. Asher (red.), The Encyclopedia of Language and Linguistics. T. 1 (44-46). Oxford-New York-Seoul-Tokyo: Pergamon Press.

Carstairs-McCarthy, A. (2006). Affixation. W: K. Brown (red.), Encyclopedia of Language and Linguistics. T. 1 (83-88). Oxford: Elsevier.

Chén, L. (2001). Budowa i rozwój wyrazów chińskich stworzonych na gruncie japońszczy$z n y$ (和製漢語の形成とその展開). Tōkyō: Kyūko shoin 汲古書院.

Chomsky, N. (2000). Minimalist inquiries. W: R. Martin, D. Michaels, J. Uriagereka. (red.), Step by step: essays on minimalist syntax in honor of Howard Lasnik (89-156). Cambridge-Mass.: MIT Press.

Chomsky, N. (2001). Derivation by phase. W: M. Kenstowicz (red.), Ken Hale: a life in language (1-52). Cambridge-Mass.: MIT Press.

Di Sciullo, A.M. (2009). Why are compounds a part of human language? A view from asymmetry theory. W: L. Rochelle, Š. Pavol (red.), The Oxford Handbook of Compounding (145-177). Oxford: Oxford University Press.

Ito, J., Mester, A. (2015). Word formation and phonological processes. W: H. Kubozono (red.), Handbook of Japanese Phonetics and Phonology (363-395). Berlin: De Gruyter.

Kageyama, T. (2001). Word Plus: The Intersection of Words and Phrases. W: J. van de Weijer, T. Nishihara (red.), Issues in Japanese Phonology and Morphology (245-276). Berlin: De Gruyter.

Kobayashi, H., Yamashita, K., Kageyema, T. (2016). Sino-Japanese words. W: T. Kageyama, H. Kishimoto (red.), Handbook of Japanese Lexicon and Word Formation (98131). Berlin: De Gruyter.

Kurisu, K. (2000). Richness of the Base and Root Fusion in Sino-Japanese, Journal of EastAsian Linguistics, 9, 147-185.

Miyaoka, Y., Tamaoka, K. (2005). An Investigation of the Right-hand Head Rule Applied to Japanese Affixes, Glottometrics, 10, 45-54.

Nagano, A. (2016). Are relational adjectives possible cross-linguistically? The case of Japanese, Word Structure, 9/1, 42-71.

Pesetsky, D., Torrego, E. (2006). Probes, goals and syntactic categories. W: Proceedings of the 7th Annual Tokyo Conference on Psycholinguistics. Keio University, Japan. Pozyskano z https://ling.auf.net/lingbuzz/000321 (pdf).

Shibatani, M. (2017). Nominalization. W: M. Shibatani, S. Miyagawa, H. Noda (red.), Handbook of Japanese Syntax (271-332). Berlin: De Gruyter.

Suzuki, H. (2010). Wyrazy sinojapońskie powstałe na gruncie języka japońskiego na przełomie upadku rządów samurajskich i restauracji Meiji (幕末明治期に生まれ た日本製の漢語). W: Badania nad językiem przełomu XVIII i XIX wieku (313-328).

T. 15. (近代語研究). Tōkyō: Musashino shoin 武蔵野書院. 
Tajima, M. (1998). Badania nad wyrażeniami zapisywanymi ideogramami chińskimi przełomu XVIII i XIX wieku (近代漢字表記語の研究). Ōsaka: Izumi shoin 和泉書院.

Wurmbrand, S. (2014). The Merge Condition: A syntactic approach to selection. W: P. Kosta, S.L. Franks, T. Radeva-Bork, L. Schürcks (red.), Minimalism and Beyond. Radicalizing Interfaces (130-166). John Benjamins: Amsterdam/Philadelphia.

\section{Streszczenie}

Celem niniejszej pracy jest podjęcie dyskusji nad morfologicznym statusem sinojapońskich morfemów japońszczyzny. Analizie zostaje poddany przede wszystkim typ ich łączliwości z innymi jednostkami. Podjęta zostaje także polemika z tradycyjnym opisem japońskim ze wskazaniem różnic między afiksami a zwykłymi morfemami słowotwórczym. Problem ten okazuje się szczególnie niebanalny, jeśli na omawiane tu jednostki spojrzeć z punktu widzenia wielosystemowości: kategorie lingwistyczne, które zostały przeszczepione z pozycyjnego języka chińskiego do systemu japońskiego posiadającego fleksję aglutynacyjną, pozwalają na postawienie pewnych ciekawych problemów na styku morfologii i składni języków naturalnych. 